\title{
Agronomic performance of maize (Zea mays L.) genotypes under Azospirillum brasilense application and mineral fertilization
}

\section{Rendimiento agronómico de genotipos de maíz (Zea mays L.) bajo la aplicación de Azospirillum brasilense y fertilización mineral}

Luiz Eduardo Tilhaqui Bertasello ${ }^{1}$, Vinicius Augusto Filla ${ }^{2}$, Anderson Prates Coelho ${ }^{2}$, Gustavo Vitti Môro ${ }^{1}$

Originales: Recepción: 27/04/2020 - Aceptación: 02/10/2020

\begin{abstract}
Maize has a high nitrogen $(\mathrm{N})$ demand; as a result, more sustainable alternatives are needed to reduce demand for mineral fertilizers. The hypothesis is that the agronomic performance of maize genotypes diverges in their potential when subjected to different supplies of $\mathrm{N}$. This study aimed to evaluate and characterize the agronomic performance of maize genotypes submitted to topdressing nitrogen fertilization and inoculation with Azospirillum brasilense and select the best genotypes within each management. An experiment was conducted in the second season of 2017, in Jaboticabal-SP (Brazil), using 48 maize genotypes in a randomized block design. Treatments consisted of: 1) application of $140 \mathrm{~kg} \mathrm{ha}^{-1}$ nitrogen, using urea as mineral fertilizer; 2) A. brasilense inoculation via soil, at a rate of 600 $\mathrm{mL} \mathrm{ha}^{-1}$, as biological fertilization. Grain yield and agronomic traits were evaluated. The data were subjected to analysis of variance (F-Test), means were compared by Scott-Knott test at $5 \%$ probability, and multivariate statistical analysis was performed by principal component analysis. The maize genotypes showed contrasting agronomic performance in relation to the nitrogen supplies evaluated. Inoculation with $A$. brasilense via soil has a significant effect on increasing maize grain yield, making it a viable and more sustainable alternative in the supply of $\mathrm{N}$. The choice of the genotype is an essential factor for the successful use of mineral nitrogen fertilization or $A$. brasiliense inoculation.
\end{abstract}

\section{Keywords}

diazotrophic bacteria $\bullet$ grain yield $\bullet$ biological nitrogen fixation $\bullet$ nitrogen

1 São Paulo State University (UNESP). School of Agricultural and Veterinarian Sciences (FCAV). Department of Agricultural Production Sciences. Genetics and Plant Breeding. Jaboticabal - 14884-900. São Paulo. Brazil. luiz.bertasello@unesp.br

2 São Paulo State University (UNESP). School of Agricultural and Veterinarian Sciences (FCAV). Department of Agricultural Production Sciences. Crop Production. 


\section{RESUMEN}

El maíz tiene una alta demanda de nitrógeno $(\mathrm{N})$, como resultado, se necesitan alternativas más sostenibles para reducir la demanda de fertilizantes minerales. La hipótesis es que el comportamiento agronómico de los genotipos de maíz diverge en su potencial cuando se someten a diferentes suministrados de N. Este estudio tuvo como objetivo evaluar y caracterizar el rendimiento agronómico de los genotipos de maíz sometidos a fertilización nitrogenada e inoculación con Azospirillum brasilense y seleccionar los mejores genotipos dentro de cada manejo. Se realizó un experimento en la segunda temporada de 2017, en Jaboticabal-SP (Brasil), utilizando 48 genotipos de maíz en un diseño de bloques al azar. Los tratamientos consistieron en: 1) aplicación de $140 \mathrm{~kg} \mathrm{ha}^{-1}$ de nitrógeno, utilizando urea como fertilizante mineral; 2) Inoculación de A. brasilense vía suelo, a razón de $600 \mathrm{~mL} \mathrm{ha-}^{-1}$, como fertilización biológica. Se evaluaron el rendimiento de granos y los rasgos agronómicos. Los datos se sometieron a análisis de varianza (prueba F), y las medias se compararon mediante la prueba de Scott-Knott con una probabilidad del 5\%, y el análisis estadístico multivariado se realizó mediante análisis de componentes principales. Los genotipos de maíz mostraron un comportamiento agronómico contrastante en relación con los suministrados de $\mathrm{N}$ evaluados. La inoculación con $A$. brasilense vía suelo tiene un efecto significativo en incrementar el rendimiento de granos de maíz, convirtiéndolo en una alternativa viable y más sustentable en el suministrado de N. La elección del genotipo es un factor esencial para el uso exitoso de la fertilización con nitrógeno mineral o la inoculación con $A$. brasiliense.

\section{Palabras claves}

bacterias diazotróficas • producción de granos • fijación biológica de nitrógeno • nitrógeno

\section{INTRODUCTION}

Proper management of nitrogen fertilization is essential for high grain yield in cereal crops such as maize. At harvest, nitrogen deficiency can reduce grain yield by 14 to $80 \%(8,28)$. Maize is socio-economically important as it is the most grown crop species worldwide $(21,23)$.

Among the soil nutrient fertilizers available, nitrogen $(\mathrm{N})$ is the most expensive fertilization cost and can reach about $30 \%$ of total production cost (10). However, when applied to the soil, it can cause environmental damages since a is usually lost by leaching and volatilization (19). In addition, nitrogen fertilizer manufacturing consumes much oil, which is a non-renewable energy source. Therefore, new alternatives need to be sought to streamline use of nitrogen fertilizers $(5,13)$, as one of the major agricultural challenges for the coming years is to produce sustainable food and optimize existing resources (17).

Studies have indicated plant breeding and Azospirillum genus bacteria inoculation as alternatives to partially supply maize nitrogen demands. These bacteria are highly capable of performing biological nitrogen fixation (BNF) (25), which can reduce use of nitrogen fertilizers.

These bacteria also play a role in plant hormone production such as auxins, cytokines, and gibberellins, which stimulate plant shoot and root growth (26), and hence plant light interception and dry mass yield (22). Such stimulus also increases plant water and nutrient uptakes by increasing root system branching (20), thereby improving corn grain yield $(4,15)$.

The results of Azospirillum brasilense inoculation depend on biotic and abiotic factors such as genotype, soil microbial community, and climate variations (14). Genotypes may have different physiological performances in terms of $\mathrm{N}$ uptake (9). Thus, identifying and selecting maize genotypes responsive to inoculation and nitrogen fertilizations is a forthcoming approach to improve crops and reduce nitrogen fertilizer use and respective environmental contamination (18).

The hypothesis for the present study is that the agronomic performance of maize genotypes diverges in their potential when subjected to nitrogen topdressing fertilization and inoculation with $A$. brasilense. This study aims to evaluate and characterize the agronomic performance of second-season maize genotypes as a function of topdressing nitrogen fertilization and $A$. brasilense inoculation via soil and select the best genotypes within each management. 


\section{MATERIAL AND METHODS}

An experiment was conducted in the second season of 2017, at the Fazenda de Ensino, Pesquisa e Extensão (FEPE) of the São Paulo State University, School of Agricultural and Veterinarian Sciences, Jaboticabal-SP (Brazil). The study area is at an average altitude of 615 meters, near the coordinates of $21^{\circ} 14^{\prime} 05^{\prime \prime} \mathrm{S}$ latitude and $48^{\circ} 17^{\prime} 09^{\prime \prime} \mathrm{W}$ longitude. According to Köppen's classification, the climate is classified as Aw, which stands for humid tropical with rainy season in summer and dry winter. The soil was classified as eutrophic Red Latosol (Oxisol) (6). The region has average precipitation of $1.425 \mathrm{~mm}$.

Soil chemical attributes and particle size were determined in the 0.00-0.20 and prior to common maize sowing. The results were $\mathrm{pH}\left(\mathrm{CaCl}_{2}\right) 5.45$; organic matter $\left(\mathrm{g} \mathrm{dm}^{-3}\right)$ 24.37; N 0.18\%; P (mg dm $\left.{ }^{-3}\right)$ 8.26; $\mathrm{K}\left(\mathrm{mmol}_{\mathrm{c}} \mathrm{dm}^{-3}\right)$ 3.08; $\mathrm{Ca}\left(\mathrm{mmol}_{\mathrm{c}} \mathrm{dm}^{-3}\right) 38.73 ; \mathrm{Mg}\left(\mathrm{mmol}_{\mathrm{c}} \mathrm{dm}^{-3}\right)$ 16.98; S (mg dm$\left.{ }^{-3}\right)$ 7.07; B (mg dm$\left.{ }^{-3}\right)$ 0.21; Fe $\left(\mathrm{mg} \mathrm{dm}^{-3}\right){ }^{\mathrm{c}} 25 ; \mathrm{H}+\mathrm{AL}\left(\mathrm{mmolc} \mathrm{dm}^{-3}\right){ }^{\mathrm{c}} 20.13$; cation exchange capacity $\left(\mathrm{mmol}_{\mathrm{c}} \mathrm{dm}^{-3}\right)$ 78.93; base saturation $74.17 \%$; clay $540 \mathrm{~g} \mathrm{~kg}^{-1}$; silt $230 \mathrm{~g} \mathrm{~kg}^{-1}$; sand $230 \mathrm{~g} \mathrm{~kg}^{-1}$.

Forty-eight maize (Zea mays L.) genotypes were used in the experiment. These correspond to 46 synthetic maize populations from random crossbreeding, which were developed by Phoenix Agricultural Ltda, as well as two commercial cultivars AL Bandeirantes (Check A) and hybrid DKB 390 VT PRO2 (Check B).

Sowing was performed on February 17, 2017. Plots were delineated in randomized blocks, arranged in strips, devised by a plot seeder. Sowing fertilization was performed using $350 \mathrm{~kg} \mathrm{ha}^{-1}$ of the 8-28-16 formulation. Each plot consisted of four 5-m long rows spaced $0.50 \mathrm{~m}$ between rows and $0.33 \mathrm{~m}$ between plants, with a population of 60,000 plants $\mathrm{ha}^{-1}$. As a useful area for evaluation and harvesting, only the two central lines were used.

All the genotypes were supplied with nitrogen by: 1) biological fixation with A. brasilense inoculation in the soil; and 2) chemical fertilization with urea as source. Both topdressing and inoculation were performed on March 23, 2017, when plants were at $\mathrm{V}_{4}$ stage.

We used the commercial inoculant Qualyfix Gramíneas ${ }^{\circledR}$ (A. brasilense, strain AbV5 and AbV6, at concentration of $5 \times 10^{8}$ cells $\mathrm{mL}^{-1}$ ), which was applied at the manufacturer's recommended rate $\left(600 \mathrm{~mL} \mathrm{ha}^{-1}\right.$ for soil spraying). The inoculant was applied to the soil with the aid of a costal sprayer at $10 \mathrm{~cm}$ from maize row. Nitrogen topdressing was performed at a rate of $140 \mathrm{~kg} \mathrm{ha}^{-1} \mathrm{~N}$, using urea as source. It was applied in continuous fillet at $10 \mathrm{~cm}$ from crop row. After fertilization and A. brasilense application, irrigation was performed by a sprinkler system. Weed and pest controls were performed according to recommendations for maize cropping (7).

The following variables were evaluated: number of vegetative days until male (MF) and female (FF) flowerings, plant height $(\mathrm{PH})$, ear height $(\mathrm{EH})$, lodging and breaking rates $(\mathrm{L}+\mathrm{B})$, stunting rate (STU), Fusarium spp. (FUS) and grain yield (GY).

We also evaluated number of plants tilted more than $45^{\circ}$ from the vertical or lodged on the soil at harvest time. This result was added to the breaking parameter, which is the number of plants with broken stem below the main ear. The data were transformed to $\sqrt{\mathrm{x}+1}$ for data normality, and later converted to percentage values.

Before threshing, five maize ear samples were collected randomly from each plot to be evaluated for Fusarium spp. (FUS) symptoms. The number of ears presenting FUS symptom was counted and transformed to $\sqrt{\mathrm{x}+1}$ for data normality and then converted to percentage.

Grain yield (GY) was obtained by threshing ears harvested within the useful area of each plot, weighing the grains and correcting to $13 \%$ moisture, and then converting the data to tons per hectare $\left(\mathrm{t} \mathrm{ha}^{-1}\right)$.

The stuting rate (STU) was analyzed according to percentage of Daubulus maidis incidence in each plot, obtained by equation 1.

$$
\text { Incidence }(\%)=\frac{\text { NPS X } 100}{\text { NTP }}
$$

where:

NPS = number of plants showing symptoms of generalized redness or yellowing and whitish streaks caused by Dalbulus maidis

NTP = total number of plants in the plot

The data were transformed to $\sqrt{\mathrm{x}+1}$, aiming at normality, and later converting them to percentage. 
During the experiment, the averages of temperature maximum and minimum and rainfall were $29.1^{\circ} \mathrm{C}, 16,6^{\circ} \mathrm{C}$ and $358 \mathrm{~mm}$, respectively (figure 1). Meteorological data were provided by the agroclimatological station at FCAV/UNESP (College of Agricultural and Veterinary Sciences - University of São Paulo State). Water was provided via sprinkler irrigation when there were longer periods with no rain. Harvesting was performed manually on $07 / 03 / 2017$, at 136 days after emergence (DAE).

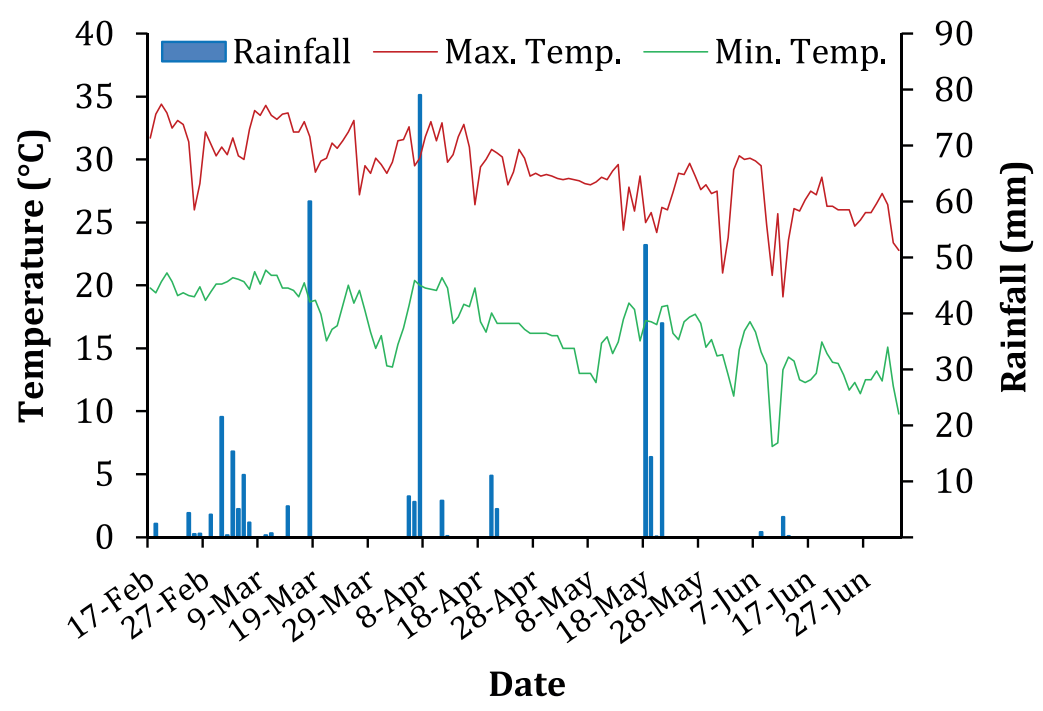

Figure 1. Rainfall (mm) and minimum and maximum temperatures $\left({ }^{\circ} \mathrm{C}\right)$ from February 17 to July 03, 2017.

Figura 1. Precipitaciones $(\mathrm{mm})$ y temperaturas mínimas y máximas $\left({ }^{\circ} \mathrm{C}\right)$ del 17 de febrero al 03 de julio de 2017.

Data from each variable was recorded separately, and genotypes and the two N supplies were considered as fixed factors. A factorial variance analysis (2 nitrogen supplies x 48 genotypes) was performed, considering all genotypes and agronomic traits. Means were compared by the Scott-Knott test at $5 \%$ probability, using AgroEstat ${ }^{\circledR}$ software (2).

After standardization, all data were submitted to principal component analysis (PCA). The number of components was chosen according to Kaiser's criterion (11), wherein eigenvalues $>1.00$ are selected. The results of principal component analysis (PC) were presented in biplot graphs, with genotypes plotted in the X-axis and matrices in the Y-axis, being represented by points. A scatterplot of the principal component analysis was used to have a clear view of the performance of each genotype in each variable. Genotypes were identified by a -2 to 2 ellipse in PC1 and PC2, wherein genotypes within the ellipse have no specific properties, while those located outside the ellipse are characterized as promising for each $\mathrm{N}$ supply. The analyses were performed using the Statistica $7.0^{\circledR}$ software (24).

\section{RESUltS AND Discussion}

The results of the analysis of variance (table 1, page 72 ) showed that $\mathrm{N}$ source had a significant effect on grain yield (GY) and on days for female flowering (FF), when exchanging the N supply via inoculation with $A$. brasilense for topdressing, Regarding the source of genotype variation, all parameters differed significantly, except for male flowering (MF) and lodging + breaking rates $(\mathrm{L}+\mathrm{B})$, These results corroborates the hypothesis that the agronomic performance of maize genotypes diverges in their potential when subjected to nitrogen topdressing fertilization and inoculation with $A$. brasilense.

The interaction GEN x NSS (genotype x N supply source) showed a significant difference only for Fusarium spp., therefore, genotypes and N supply vary differently for incidence of this disease (table 1, page 72). Similar results were observed by Khan and Doohan (2009), who found decreases between 12 and $21 \%$ in the disease incidence for inoculated plants. 
These authors pointed out that favorable conditions for Fusarium spp. development may have been due to an increase in fertilization rates, besides being directly related to leaf disease intensity.

In both N supply systems, the genotypes presented overall GY means of $2.14 \mathrm{t} \mathrm{ha}^{-1}$ (table 1), among which Check A and Check B stood out with averages of 3.23 and 3.55 t ha $^{-1}$, respectively (table 1). These averages may reflect the low L + B rates, STU and FUS of these genotypes. In this same context, genotype 22 had the lowest yield, with an average of $1.21 \mathrm{t} \mathrm{ha}^{-1}$, which may be linked to other to other factors such as the low $\mathrm{PH}$ and high staging value presented by this genotype, in addition to the above average $\mathrm{L}+\mathrm{B}$ rates (table 2 , page 73-74).

Table 1. Simple factorial variance analysis of 48 maize genotypes in response to topdressing nitrogen fertilization and Azospirillum brasilense inoculation.

Tabla 1. Análisis de varianza factorial simple de 48 genotipos de maíz en respuesta a la fertilización nitrogenada y la inoculación de Azospirillum brasilense.

\begin{tabular}{|l|c|c|c|c|c|c|c|c|c|}
\hline \multirow{2}{*}{\multicolumn{1}{|c|}{ SV }} & \multicolumn{7}{|c|}{ F Test } \\
\cline { 2 - 10 } & DF & GY & MF & FF & PH & EH & L + B & STU & FUS \\
\hline NSS & 1 & $7.57^{* *}$ & $0.88^{\text {ns }}$ & $65.33^{*}$ & $0.01^{\text {ns }}$ & $0.01^{\text {ns }}$ & $0.19^{\text {ns }}$ & $0.58^{\text {ns }}$ & $0.01^{\text {ns }}$ \\
\hline GEN & 47 & $0.82^{* *}$ & $6.10^{\text {ns }}$ & $12.63^{* *}$ & $0.03^{* *}$ & $0.01^{* *}$ & $45.18^{\text {ns }}$ & $1.47^{* *}$ & $0.18^{* *}$ \\
\hline GEN ${ }^{*}$ NSS & 47 & $0.13^{\text {ns }}$ & $4.06^{\text {ns }}$ & $3.68^{\text {ns }}$ & $0.01^{\text {ns }}$ & $0.01^{\text {ns }}$ & $6.66^{\text {ns }}$ & $0.21^{\text {ns }}$ & $0.15^{*}$ \\
\hline Mean & - & 2.14 & 63.42 & 62.81 & 1.67 & 0.90 & 16.87 & 26.63 & 12.39 \\
\hline CV & - & 24.29 & 3.27 & 3.59 & 5.58 & 8.66 & 29.29 & 18.33 & 11.69 \\
\hline
\end{tabular}

* Significant at $5 \%$ probability and ** Significant at $1 \%$ probability by the F-test: SV: source of variation; DF: degrees of freedom; NSS: nitrogen supply source; GEN: genotype; GEN * NSS: interaction between genotype and nitrogen supply; CV: coefficient of variation (\%); ns: not significant; GY: grain yield ( $\mathrm{tha}^{-1}$ ); MF: male flowering

(days); FF: female flowering (days); PH: plant height (m); EH: ear height (m); L + B: lodging and breaking of plants (\%); STU: stunting (\%); FUS: Fusarium spp. (\%)

* Significativo al 5\% de probabilidad y ** Significativo al 1\% de probabilidad según lo teste-F: FV: fuente

de variación; GL: grados de libertad; FSN: fuente de suministro de nitrógeno; GEN: genotipo; GEN * FSN: interacción entre genotipo y suministro de nitrógeno; CV: coeficiente de variación (\%); ns: no significativo; GY: rendimiento de granos (t ha-1); PH: altura de la planta (m); EH: altura de espiga (m); MF: floración masculina (días); FF: floración femenina (días); L: vuelco de plantas (\%); B: quebradura de tallos (\%); STU: Cinta roja (\%); FUS: Fusarium spp. (\%).

In comparing the performance of genotypes with respect to the two $\mathrm{N}$ supply sources, only genotypes 27 and 34 showed significant differences in GY. These genotypes presented higher GY by A. brasilense application, with increments of 1.08 and 1.19 t ha $^{-1}$, respectively, in relation of mineral fertilizantion (table 2, page 73-74). These results are in agreement with those found by Müller et al. (2016), who obtained increases of up to 28\% in grain yield after inoculation of $A$. brasilense in relation to genotypes with topdressing nitrogen fertilization.

Superior grain yield was also reported by Araújo et al. (2014) after inoculating maize with the same diazotrophic bacteria. When topdressed (table 2, page 73-74), 31.25\% of the genotypes were superior to the others for GY. The same was observed in A. brasilense inoculation, in which $45.83 \%$ of the genotypes differed from the others regarding their response to inoculation. For both N supply sources, each genotype showed significant GY differences, therefore, this trait is greatly influenced either by chemical or biological sources.

Genotypes showed significant differences in PH and EH when comparing both N supplies. Genotype 18 increased plant height and ear insertion height by $0.20 \mathrm{~m}$ when inoculated with $A$. brasilense, that is, it was responsive to diazotrophic bacteria application (table 2, page 73-74). Favorable effects provided by bacteria may have occurred due to changes in the root system of inoculated maize plants, leading to improvements in plant growth, water absorption, and nutrient intake (3), highlighting the height gains.

Genotype 32 presented the same increase $(0.20 \mathrm{~m})$ in plant and EH when urea was supplied as topdressing (table 2, page 73-74); therefore, this genotype was more responsive to urea fertilization in terms of plant height. This result corroborates Vogel et al. (2013), who observed that nitrogen-deficient maize plants are more capable of synthesizing carbohydrates during photosynthesis, thus growing more. 


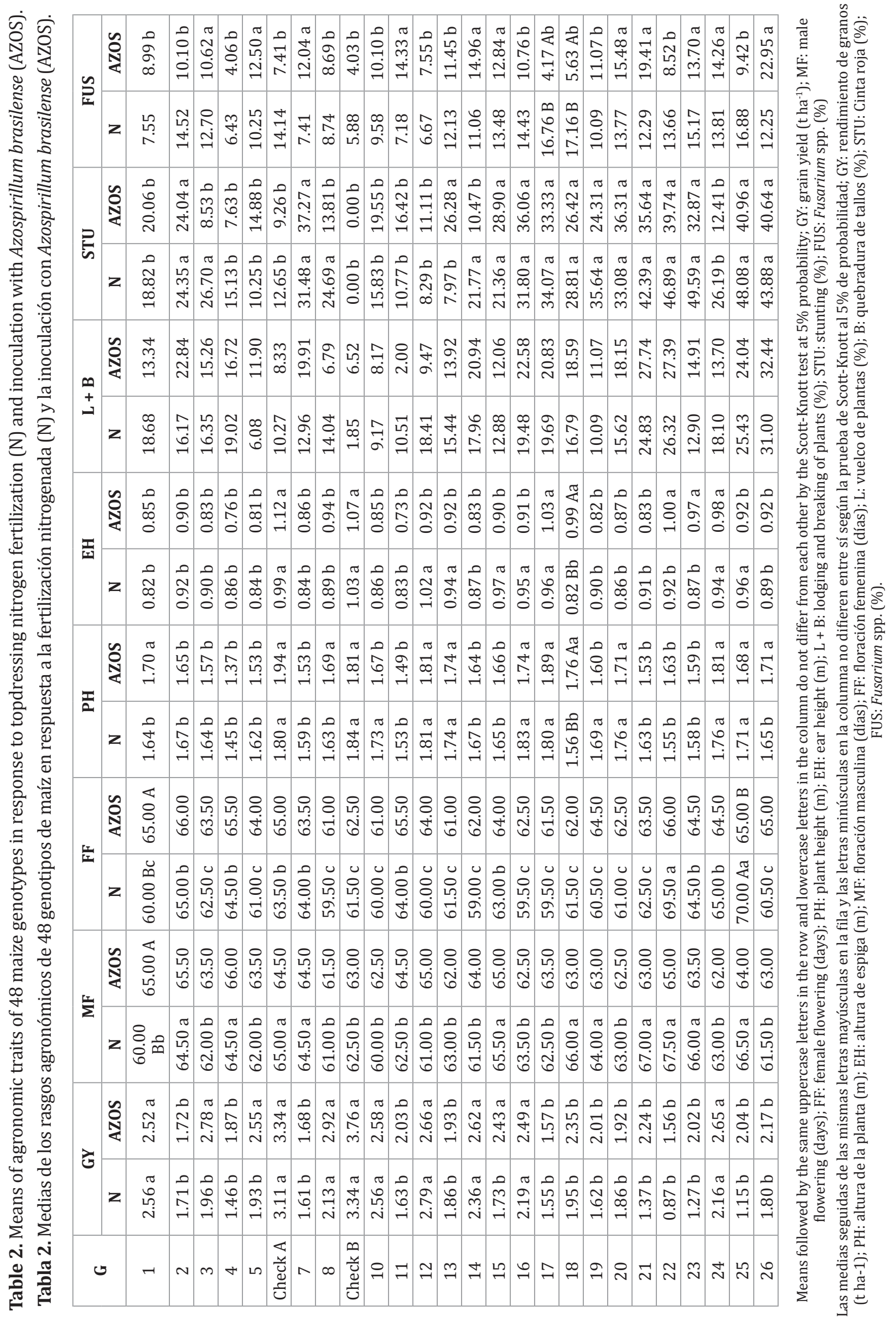




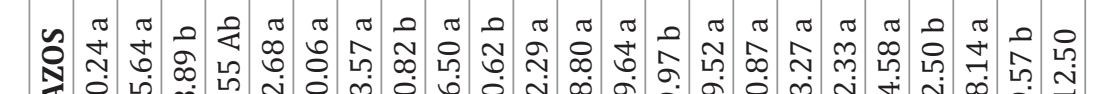

空

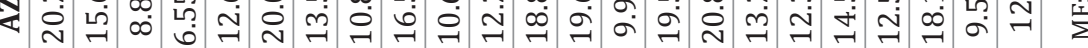

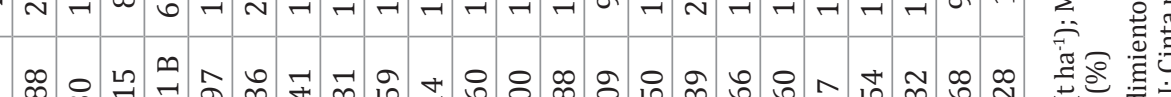
付 ம்

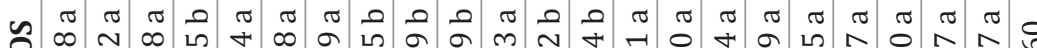

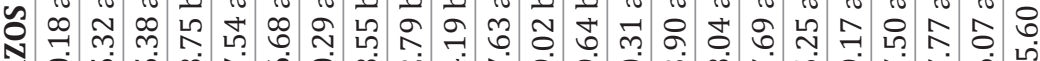
른

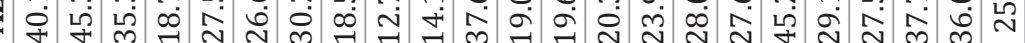
is

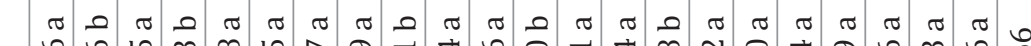

$z$ 누

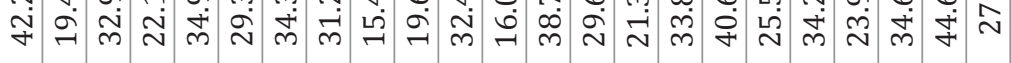

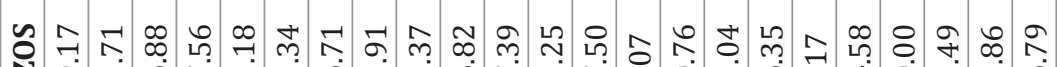
$\infty$

\&

$\stackrel{+}{+}$

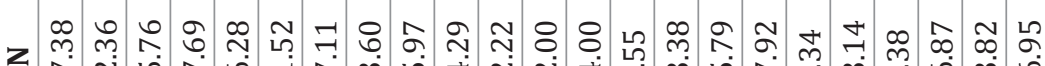

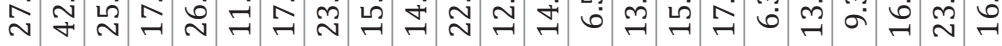

ஜ 산 포

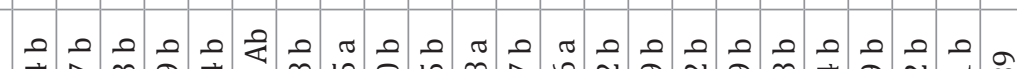

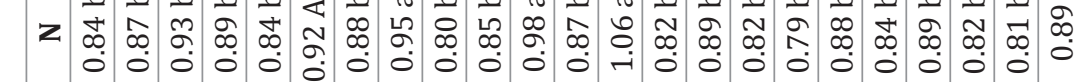
こ 존

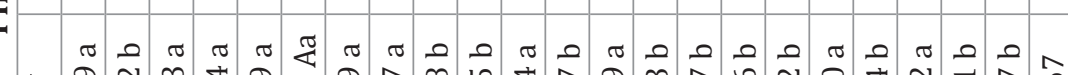

z

은 웅 웅 《 厌

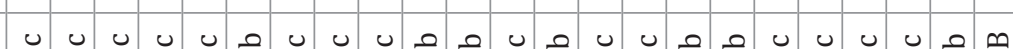

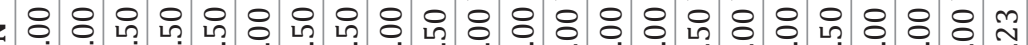
๑઼

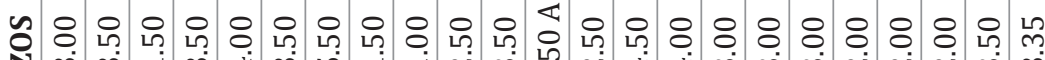
य $\sum$

م

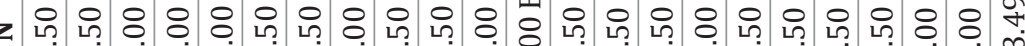
ปூ

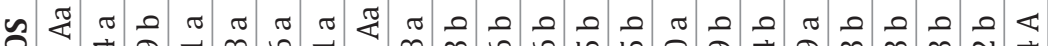

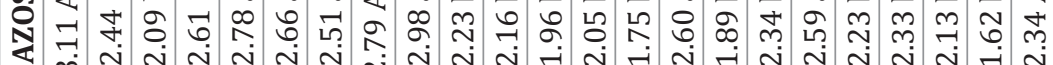
त्र

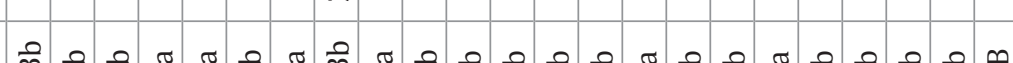
m ஸ்

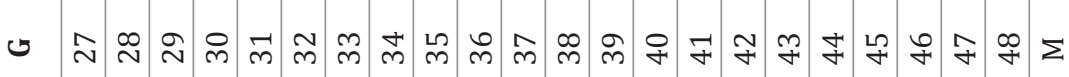
을 穵

¿ई ప艹 花这羿

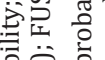

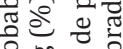

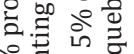
유 艺学官

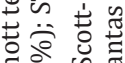
웡 䒕 运 ब 这 스묘물

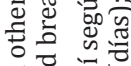
瑧

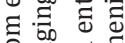

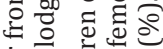

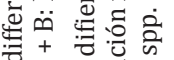

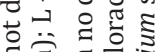

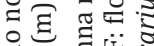
ह 苟

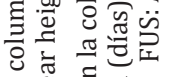
\& 至突号

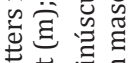
范药 卷 艺司은 긍 $\frac{\pi}{2}$ 量 范范药

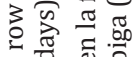
$\underbrace{0}_{0}$ is के $\Xi \Xi \frac{\pi}{3}$ 。

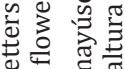

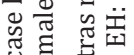
过 空空 商茪蓄 芯 묨ㅇㅁㅇ 일

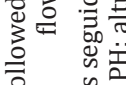


Both $A$. brasilense inoculated and urea topdressed plants obtained similar increase in PH and $\mathrm{EH}$, being thus responsive to both $\mathrm{N}$ supply sources. These responses can reduce final production cost and environmental impact.

Regarding the incidence of $L+B$, all genotypes behaved similarly with no significant differences between inoculation and topdressing. When comparing the 48 genotypes for each $\mathrm{N}$ supply, 68.75 and $62.50 \%$ of the genotypes were more responsive to topdressing and inoculation, respectively (table 2, page 73-74). Moreover, no disease infestation was observed in genotype Check B in both environments, Therefore, this genotype may be tolerant to vector transmission (leafhopper - Dalbulus maidis), thus benefiting plant development and health in these plots, as well as improving productivity.

By comparing Fusarium spp. incidence in both N supply sources, significant differences were observed in genotypes 17,18 , and 30 , which showed higher tolerance when inoculated with $A$. brasilense. This benefit may be due to a better responsiveness to plant inoculation, possibly due to an improved root system with higher nutrient absorption capacity, which is also reflected in healthier and better nourished plants. However, when topdressed, genotypes showed no significant differences, therefore, all plants behaved similarly. On the other hand, when $\mathrm{N}$ is supplied by biological means, a significant difference was shown on $54.16 \%$ of the genotypes, thus highlighting a possible response of inoculation with the bacteria.

By analysis of principal components (PC), genotype distribution was evaluated for each $\mathrm{N}$ supply source, using a biplot graph method (figure 2).
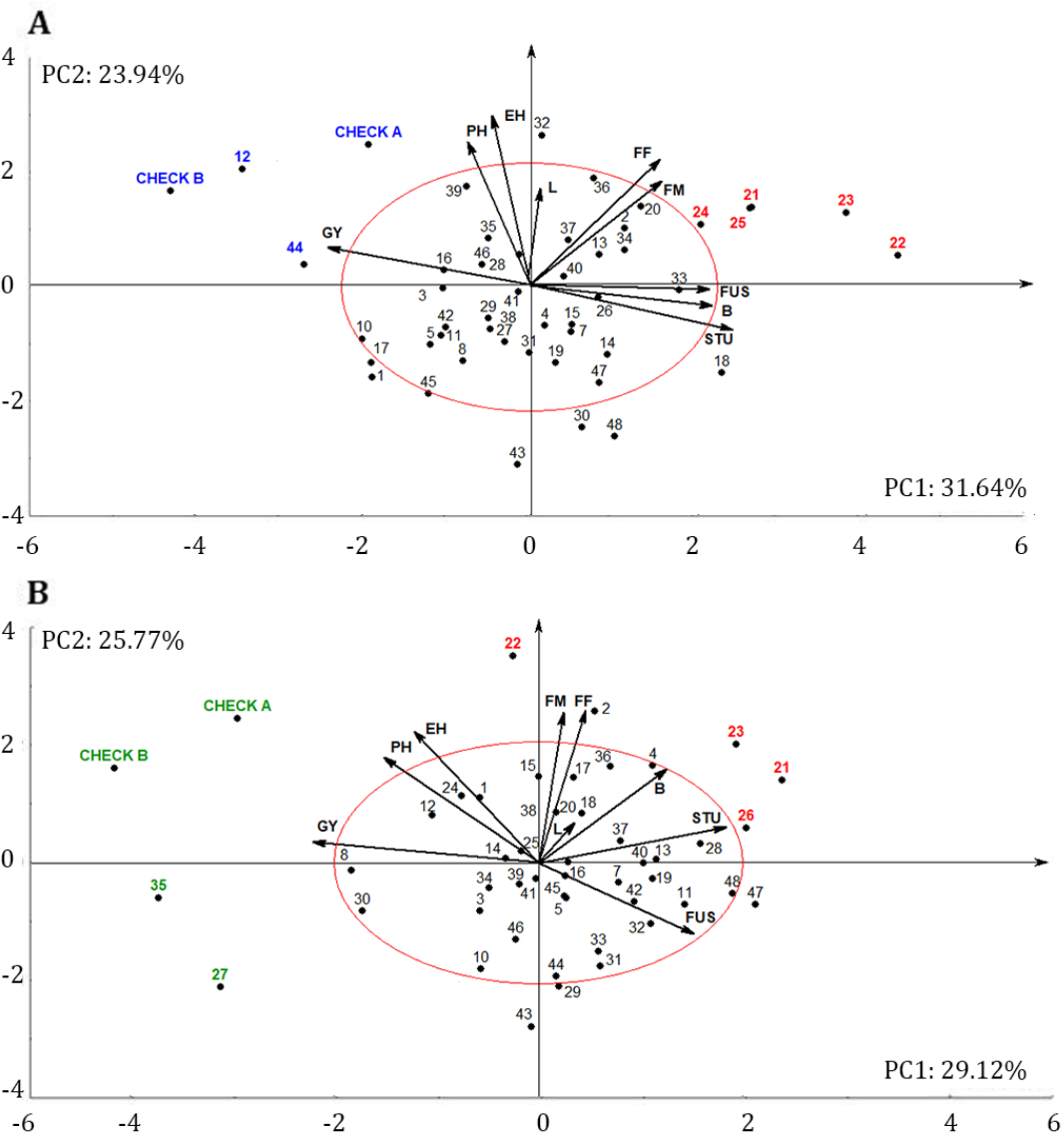

Figure 2. Biplot dispersion graph of 48 maize genotypes supplied with nitrogen topdressing

(A) and inoculated with $A$. brasilense via soil (B). GY: grain yield ( $\mathrm{t} \mathrm{ha}^{-1}$ ); $\mathrm{PH}$ : plant height

(m); EH: ear height (m); MF: male flowering (days); FF: female flowering (days); L: plant

lodging (\%); B: plant breakage (\%); STU: stunting (\%); FUS: Fusarium spp. (\%).

Figura 2. Gráfico de dispersión biplot de 48 genotipos de maíz suministrados con nitrógeno urea (A) y inoculacion con $A$. brasilense aplicado al suelo (B). GY: rendimiento

de granos ( $\mathrm{t} \mathrm{ha}^{-1}$ ); PH: altura de la planta (m); EH: altura de espiga (m); MF: floración masculina (días); FF: floración femenina (días); L: vuelco de plantas (\%); B: quebradura de tallos (\%); STU: Cinta roja (\%); FUS: Fusarium spp. (\%). 
When fertilized with urea topdressing, the first two PCs explained 55.58\% of the original data variability (31.64\% and 23.94\%, respectively) (figure 2A, page 75). As for the biological supply with $A$. brasilense inoculation, $54.89 \%$ of the original data variability was explained by the first two PCs (29.12\% and 25.77\% respectively) (figure 2B, page 75 ).

For nitrogen fertilization in topdressing (figure 2A, page 75), the genotypes Check A, Check B, 12, and 44 were discriminated by the parameters grain yield, plant height, and ear height. Check B was the most productive genotype, with high values of plant height and ear height, and the lowest values of incidence of lodging + breaking, stunting, and Fusarium spp.

Genotype 44 had the second-highest yield but high values for STU and FUS, which indicates problems in plant development and grain quality. In turn, genotypes 43 and 48 showed high values of male and female flowerings, and stunting but low values for GY, PH, and EH. Because of such characteristics, these genotypes should be discarded from breeding programs. The same was observed in genotypes 1,18 , and 30; yet, they had grain yields considered above the general average and with high values for L + B, STU, and FUS as well. Genotype 32 was discriminated by $\mathrm{PH}$ and $\mathrm{EH}$, presenting a significant difference between the sources of $\mathrm{N}$ supply, in addition to values above the general average for grain yield and Fusarium spp.

On the positive side of the X-axis (figure 2A, page 75), it can be noted that genotypes $21,22,23,24$, and 25 were discriminated by lower GY, which may be explained by high percentage of $\mathrm{L}+\mathrm{B}$, stunting and FUS, which directly affect grain yield, besides presenting the longest flowering cycles.

For inoculation with $A$. brasilense (figure $2 \mathrm{~B}$, page 75 ), it can be noted on the negative side of the $\mathrm{X}$-axis that the genotypes Check $\mathrm{A}$, Check $\mathrm{B}, 27$, and 35 were characterized by the variables GY, $\mathrm{PH}$, and $\mathrm{EH}$, corroborating results shown in table 2 (page 73-74). Check B was the most productive and with above-average values for $\mathrm{PH}$ and $\mathrm{EH}$, as well as lower rates of $\mathrm{L}+\mathrm{B}$, STU and FUS.

Genotype Check A presented the second highest GY, the highest values for PH and EH, besides good plant health. Genotype 35 had the fourth highest yield but low $\mathrm{PH}$ and $\mathrm{EH}$, with above average values for incidence of FUS. Despite the high GY, Genotype 27 also had higher and undesirable indices for lodging, breaking, stunting, and FUS Genotype 43 showed lower value for GY, PH and EH but high rates for L + B, STU and FUS. when compared to the genotypes located on the upper-left side of the graph (figure 2, page 75).

Genotype 2 presented low grain yield in relation to the above genotypes, presenting late flowering and above-average values for $\mathrm{L}+\mathrm{B}$. The same was seen in genotype 47 , which also showed above-average values for incidence of STU and FUS. Genotype 22 presented high $\mathrm{EH}$ and low presence of FUS. However, it presented high values for L $+\mathrm{B}$ and STU but later flowering and the lowest grain yield (figure 2B, page 75).

On the positive side of the X-axis (figure 2, page 75), it can be noted that the genotypes 21,23 , and 26 were in the opposite direction to the others, which indicates low GY and high $\mathrm{L}+\mathrm{B}$ values, as well as high incidence of STU and FUS, which directly affect plant development and yield. Therefore, these genotypes may have presented the lowest responses to A. brasilense inoculation.

The hypothesis tested in the present study was confirmed, as the maize genotypes showed different agronomic performance when submitted to topdressing mineral fertilization and inoculation with $A$. brasilense via soil. It was observed that genotypes 27,34 and 35 showed superior agronomic performance when inoculated with $A$. brasilense, while genotypes 12 and 44 obtained higher agronomic performance under nitrogen mineral fertilization.

\section{Conclusions}

The maize genotypes showed contrasting agronomic performance in relation to the nitrogen supplies evaluated. Inoculation with $A$. brasilense via soil has a significant effect on increasing maize grain yield, making it a viable and more sustainable alternative in the supply of N. However, the responses of agronomic attributes vary with the genotype. The choice of the genotype is an essential factor for the successful use of mineral nitrogen fertilization or A. brasiliense inoculation. 


\section{REFERENCES}

1. Araújo, R. M.; Araújo, A. S. F.; Nunes, L. A. P. L.; Figueiredo, M. V. B. 2014. Response of green corn to Azospirillum brasilense inoculation and N levels. Ciência Rural. 44: 1556-1560.

2. Barbosa, J. C.; Maldonado Junior, W. 2014. AgroEstat: Sistema para análises estatísticas de ensaios agronômicos Versão 1.1. Departamento de Ciências Exatas. Jaboticabal. Brasil.

3. Bashan, Y.; Bashan, L. E. 2010. How the plant growth-promoting bacterium Azospirillum promotes plant growth - a critical assessment. Advances in Agronomy. 108: 77-136. https://doi.org/ 10.1016/S0065-2113(10)08002-8.

4. Braccini, A. L.; Dan, L. G. M.; Piccinin, G. G.; Albrecht, L. P.; Barbosa, M. C.; Ortiz, A. H. T. 2012. Seed inoculation with Azospirillum brasilense associated with the use of bio-regulators in maize. Revista Caatinga. 25: 58-64. http://dx.doi.org/10.1590/1678-4499.2017273.

5. Dartora, J.; Guimarães, V. F.; Marini, D.; Sander, G. 2013. Adubação nitrogenada associada à inoculação com Azospirillum brasilense e Herbaspirillum seropedicae na cultura do milho. Revista Brasileira de Engenharia Agrícola e Ambiental. 17: 1023-1029.

6. Embrapa (Empresa Brasileira de Pesquisa Agropecuária). 2018. Sistema brasileiro de classificação de solos. $5^{\text {th }}$ ed. Brasília. Embrapa. 356 p.

7. Embrapa Milho e Sorgo. 2015. Cultivo do milho. 9 ed. Embrapa Milho e Sorgo, Sete Lagoas, Brasil. (Sistemas de Produção, 1).

8. Garcia, M. M.; Pereira, L. C.; Braccini, A. L.; Angelotti, P.; Suzukawa, A. K.; Marteli, D. C.; Felber, P. H.; Bianchessi, P. A.; Dametto, I. B. 2017. Effects of Azospirillum brasilense on growth and yield compounds of maize grown at nitrogen limiting conditions. Revista de Ciências Agrárias. 40: 353-362.

9. Heinz, R.; Pereira Ribeiro Teodoro, L.; Gonçalves, M. C.; de Azevedo Peixoto, L.; Lopes Bhering, L.; Teodoro, P. E. 2020. Potential of maize (Zea mays L.) populations derived from commercial single-cross hybrids for extraction of partially inbred lines under different nitrogen availability. Revista de la Facultad de Ciencias Agrarias. Universidad Nacional de Cuyo. Mendoza. Argentina. 52(2): 32-42.

10. IMEA (Instituto Matogrossense de Economia Agropecuária). 2019. Custo de produção do milho Safra 2018/2019. http://www.imea.com.br/upload/publicacoes/arquivos/240420181 95433.pdf (Accessed: August 2019).

11. Kaiser, H. F. 1958. The varimax criterion for analytic rotation in factor analysis. Psychometrika. 23: 187-200. http://dx.doi.org/10.1007/BF02289233.

12. Khan, M. R.; Doohan, F. M. 2009. Bacterium-mediated control of Fusarium spp. head blight disease of wheat and barley and associated mycotoxin contamination of grain. Biological Control. 48: 42-47.

13. Marini, D.; Guimarães, V. F.; Dartora, J.; Lana, M. D. C.; Pinto Júnior, A. S. 2015. Growth and yield of corn hybrids in response to association with Azospirillum brasilense and nitrogen fertilization. Revista Ceres. 62: 117-123. http://dx.doi.org/10.1590/0034-737X201562010015.

14. Müller, T. M.; Sandini, I. E.; Rodrigues, J. D.; Novakowiski, J. H.; Basi, S.; Kaminski, T. H. 2016. Combination of inoculation methods of Azospirillum brasilense with broadcasting of nitrogen fertilizer increases corn yield. Ciência Rural. 46: 210-215.

15. Pereira, L. M.; Pereira, E. M.; Revolti, L. T. M.; Zingaretti, S. M.; Moro, G. V. 2015. Seed quality, chlorophyll content index and leaf nitrogen levels in maize inoculated with Azospirillum brasilense. Revista Ciência Agronômica. 46: 630-637.

16. Quadros, P.; Roesch, L.; Silva, P.; Vieira, V.; Roehrs, D.; Camargo, F. 2014. Desempenho agronômico a campo de híbridos de milho inoculados com Azospirillum. Revista Ceres. 61: 209-218.

17. Ray, D. K.; Mueller, N. D.; West, P. C.; Foley, J. A. 2013. Yield trends are insufficient to double global crop production by 2050. PLoSone. 8: e66428.

18. Revolti, L. T. M.; Caprio, C. H.; Mingotte, F. L. C.; Môro, G. V. 2018. Azospirillum spp. potential for maize growth and yield. African Journal of Biotechnology. 17: 574-585.

19. Sá, J. C. M.; Lal, R.; Cerri, C. C.; Lorenz, K.; Hungria, M.; Carvalho, P. C. F. 2017. Low-carbon agriculture in South America to mitigate global climate change and advance food security. Environment International. 98: 102-112.

20. Saikia, S. P.; Bora, D.; Goswami, A.; Mudoi, K. D.; Godoi, A. A. 2012. Review on the role os Azospirillum in the yield improvement of non-leguminous crops. African Journal of Microbiology Research. 6: 1085-1102.

21. Sinyolo, S.; Mudhara, M.; Wale, E. 2017. The impact of social grant dependency on smallholder maize producers' market participation in South Africa: Application of the double-hurdle model. South African Journal of Economic and Management Sciences. 20: 1-10.

22. Sivasakthivelan, P.; Saranjaj, P. 2013. Azospirillum and its formulations: A Review. International Journal of Microbiological Research. 4: 275-287.

23. Snapp S. S.; Grabowski, P.; Chikowo, R.; Smith. A.; Anders, E.; Sirrine, D.; Chimonyo, V.; Bekunda, M. 2018. Maize yield and profitability tradeoffs with social, human and environmental performance: Is sustainable intensification feasible? Agricultural Systems. 162: 77-88.

24. Statsoft. 2007. Statistica: data analysis software system version 7. StatSoft. Tulsa. EUA. 
25. Szilagyi-Zecchin, V. J.; Marriel, I. E.; Silva, P. R. F. 2017. Productivity of maize inoculated with Azospirillum brasilense with different doses of nitrogen cultivated in Brazilian field. Revista Ciências Agrárias. 40: 795-798.

26. Taiz, L.; Zeiger, E. 2013. Fisiologia vegetal. 5. ed. Porto Alegre. Artmed. 954 p.

27. Vogel, G. F.; Martinkoski, L.; Bittencourt, H. V. H.; Grillo, J. F. 2013. Agronomic performance of Azospirillum brasilense on wheat crops. Applied Research and Agrotechnology. 6: 111-119.

28. Wei, S.; Wang, X.; Li, G.; Qin, Y.; Jiang, D.; Dong, S. T. 2019. Plant density and nitrogen supply affect the grain-filling parameters of maize kernels located in different ear positions. Frontiers in plant science. 10: 1-13.

\section{ACKNOWLEDGMENTS}

The study was supported by the Coordenação de Aperfeiçoamento de Pessoal de Nível Superior (CAPES) - under financing code 001. The authors also thank the Universidade Estadual Paulista (UNESP) and the Fundação de Amparo à Pesquisa do Estado de São Paulo (FAPESP) for financial support. 